\title{
PASTURE SPECIES FOR NORTHLAND
}

\author{
J. P. LAMBERT \\ Grasslands Division, Department of Scientific and \\ Industrial Research, Kaikohe
}

UNDER the usual management system, pasture surpluses are converted into fodder for feeding in periods of shortage, and sheep or cattle are grazed on pastures most of the year. It is this type of management which influences the present evaluation of pasture species. Whether this outlook is to continue is debatable, but it can be said that the potential production of many species is rarely achieved in practice.

\section{TRIALS}

It is intended, first, to examine the seasonal yields of a number of grass species.

The grasses under trial were those which usually are associated with medium to high fertility conditions, and since many species can produce at lower levels no examination was made under poorer conditions.

Simple mixtures of one grass plus red and white clovers were sown in autumn 1960, on two soils, at the Kaikohe station of the Grasslands Division, Department of Scientific and Industrial Research (J. P. Lambert, unpubl. data). The soils were Wairoro clay loam, an alluvial soil, and Waiotu friable clay, a semi-mature soil derived from basalt. Both sites were subject to winter frosts. The grass species were 'Grasslands Ruanui' perennial (Lolium perenne L.), 'Grasslands Manawa' (L. perenne L. x L. multiflorum Lam.) and 'Grasslands Ariki' (Manawa $\mathbf{x}$ Ruanui) ryegrasses, and 'Grasslands A panui' cocksfoot (Dactylis glomerata L.) paspalum (Paspalum dilatatum Poir.); Kikuyu (Pennisetum clandestinum Hochst.), and Welsh Plant Breeding Station S170 tall fescue (Festuca arundinacea Schreb.). The paspalum was of Australian commercial origin, and the Kikuyu was of local roadside origin.

On the alluvial soil, the species were sown both in plots for mowing yields, and in grazing paddocks. On the volcanic soil, only grazing paddocks were sown. In each of the grazing trials, grazing was rotational with dry sheep, over six paddocks of each species. 
MOWING AND GRAZING

Under mowing, the herbage grew to a height of 4 in. before being mown to $11 / 2$ in. Yields from these plots are shown in Fig. 1.

Under grazing, the pastures grew to the same height between grazing on both soils. Figure 2 shows how the species yielded on the alluvial soil, and Fig. 3 the yields on the volcanic soil.

The seasonal pattern of production was similar in each of the three trials. The main differences between the mowing and the grazing yields were in the great reduction in paspalum under grazing, and the increase in "other species", mainly Yorkshire fog (Holcus lanatus L.) and browntop (Agrostis tenuis Sibth.).

The winter yield of the sown grass component was higher than the summer yield in the case of Ruanui ryegrass in each trial. This was true of Ariki ryegrass and the tall fescue in the mowing trial only.

The winter yield of paspalum and Kikuyu was very low in each trial.

On the volcanic soil, the production of sown grass was about $100 \%$ higher than on the alluvial soil for all species, except paspalum where it was $50 \%$ higher.

Soil type obviously has had a marked effect on production, as has mowing compared with grazing, especially with paspalum.

\section{Dry Weather Production}

When both grass and clover in ryegrass plots were wilting in dry weather, the herbage in paspalum and Kikuyu plots was still fresh and growing.

Table 1 shows the percentages of soil moisture present under several swards in the mowing plots on Wairoro clay loam at a period such as that described above.

TABLE 1: SOIL WATER PERCENTAGES

Wairoro Clay Loam. Grasslands Division, Kaikohe. January 23, 1963

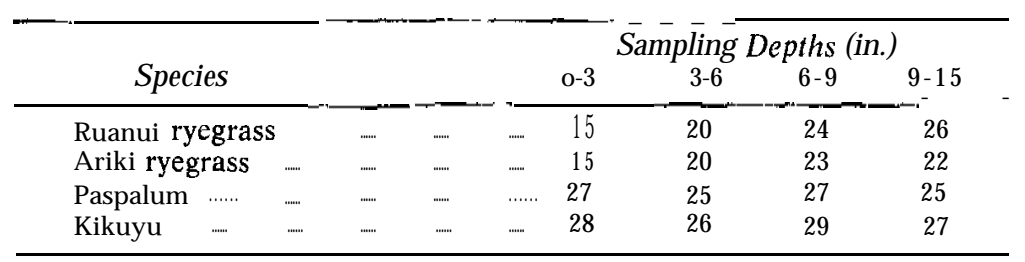




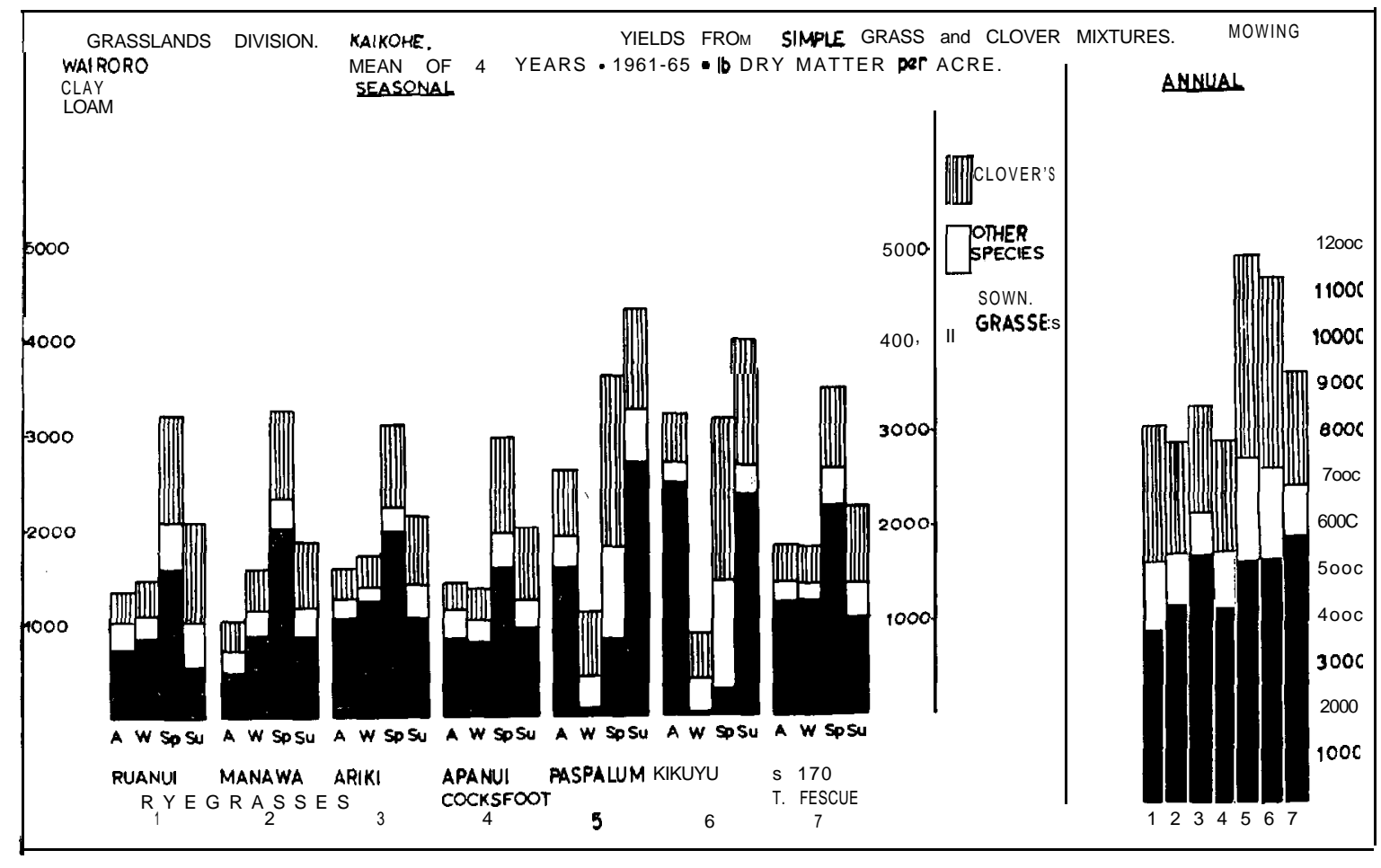




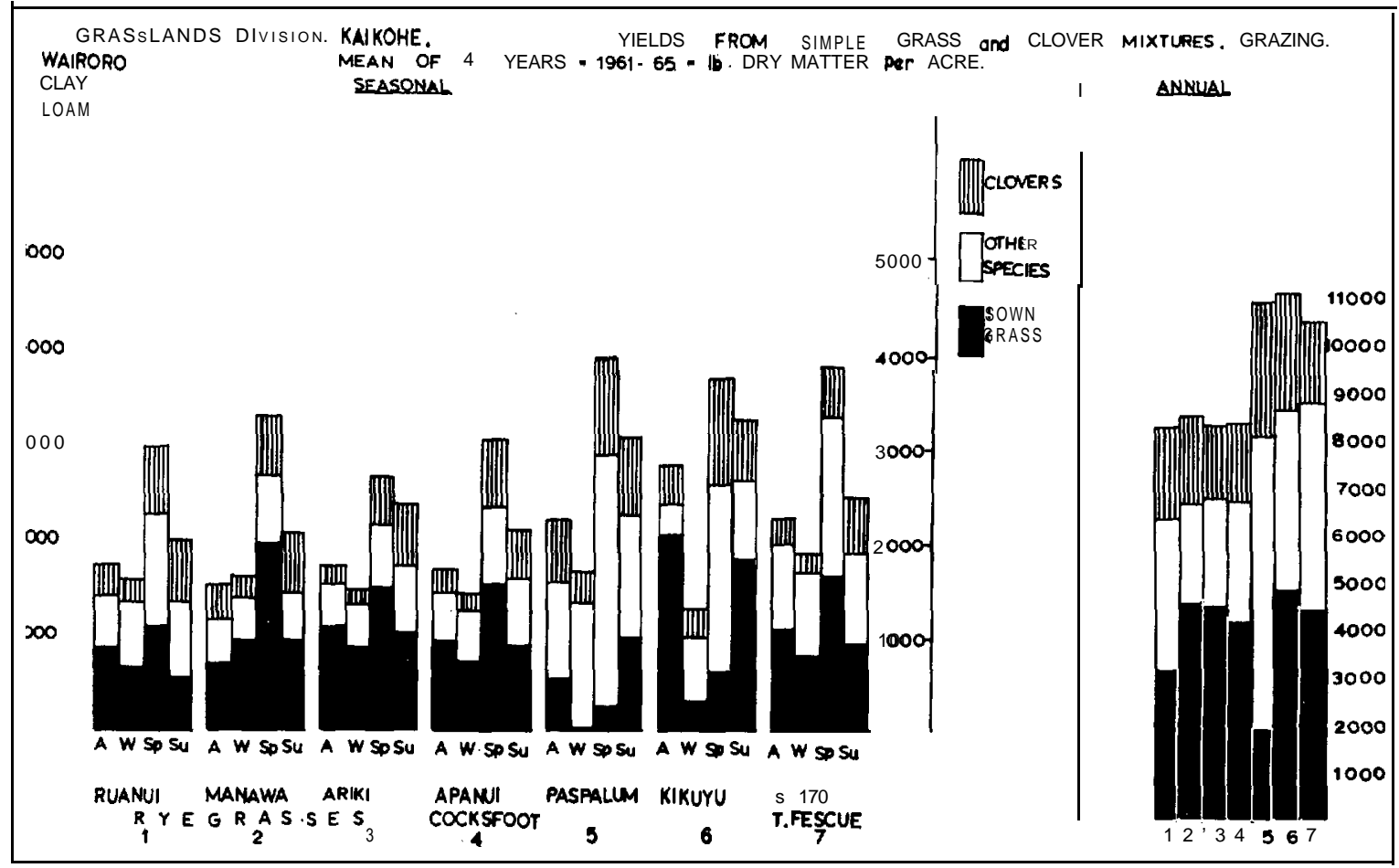

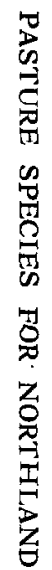

FIG. 2 


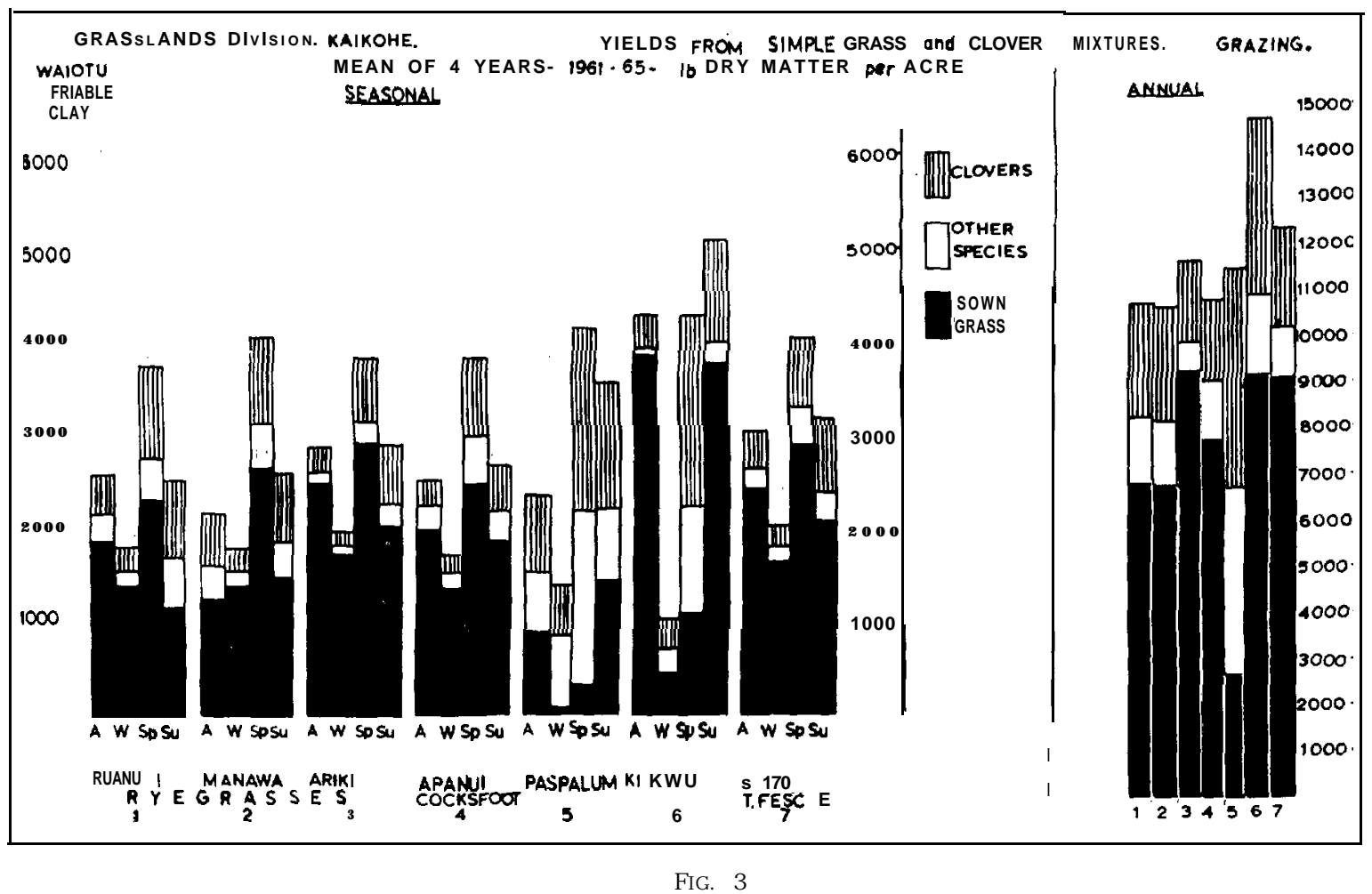


TABLE 2: EFFECT ON YIELD OF ADDED WATER Dry Weight of Herbage in lb per Acre $\times 100$. Wairoro Clay Loam. Grasslands Division, Kaikohe. January to April, 1965

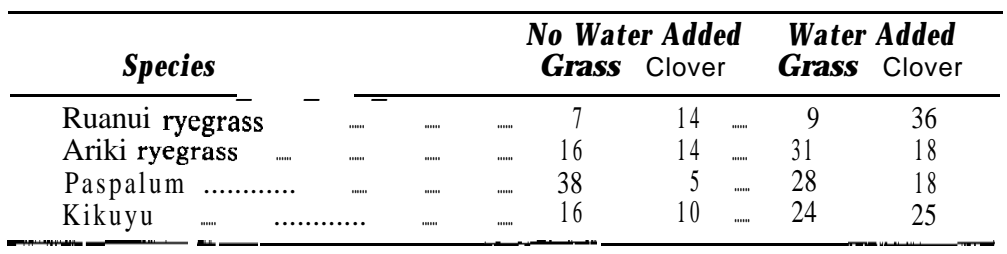

Rainfall in the preceding December was 5 in. and in January 1.1 in.

Water was added to some of the plots during January to April 1965, sufficient to maintain the soil in the ryegrass plots at about field capacity. The effect of the added water on the sown grass and clover components of the sward is shown in Table 2.

Rainfall during the period was, in inches, December 4.75, January 11.09, February 4.45, March 2.61, A pril 1.44.

Individual yields showed that considerable responses were obtained even in January. There is no doubt that a marked increase followed the addition of water. While Ruanui ryegrass itself did not respond well, the associated clover did. A riki ryegrass doubled without a big increase in clover. Paspalum production fell while its associated clover production rose considerably. Kikuyu also made a marked increase, as well as its companion clover. The anomalies in the table are matters for speculation at present.

\section{DISCUSSION}

If recommendations were based on the mowing trial the most consistent producers would be Ariki ryegrass and S170 tall fescue, but the summer growth of paspahim and Kikuyu was impressive, as was the autumn production of Kikuyu. Mitchell (1963) estimated that the potential growth of a ryegrass-dominant pasture at Kaikohe, during the three best months, is four times that of the three worst months. In the ryegrasses, cocksfoot, and tall fescue pastures, winter production has been about half that of spring, and three-quarters that of summer, which emphasizes the limitation of growth in summer, on both soils. The responses to added water support this. When grazing was 
applied, paspalum production fell to a surprising extent on the more fertile volcanic soil. This effect of the animal may be related to the removal-of foliage by grazing, to the effect of treading (Edmond, 1963), or to competition from other species.

Beyond this, knowledge gained from observation still needs to be applied, and it can be repeated that the potential production of present species has not yet been approached in practice.

Ruanui perennial ryegrass is still the basis of most pasture mixtures in Northland. It exhibits the same summer weaknesses as developed in the trials, but survives under many different systems of management.

A riki ryegrass can present a problem in a tendency to suppress the clover. Obvious ways of overcoming this are to sow minimum amounts of seed of this variety in a mixture and to prevent over-growth with adequate stocking. A more vigorous white clover may help overcome this problem, too. In observing pasture in N orthland, it appears that, if management is adequate, this ryegrass could replace Ruanui perennial ryegrass, giving an improvement in producticn in summer as well as in winter. Its persistency under hard grazing seems to be assured. These remarks generally support those of Goold ( 1966).

Manawa ryegrass, formerly known as short rotation ryegrass, has persisted well, but under trial conditions has not shown any seasonal production levels which were not generally surpassed by A riki ryegrass except in the early years of establishment. There seems to be good reason to use this ryegrass in establishing pasture as part of the ryegrass component, since its early growth is better than that of the other ryegrasses.

A panui cocksfoot has shown good production in a simple mixture, producing similarly to the ryegrasses. Some study of the production of this cocksfoot when sown in a seeds mixture with ryegrass shows that, in pastures now seven years old, it has provided from $2 \%$ to $20 \%$ of the herbage over the past three years. In these pastures, Ruanui ryegrass produced $40 \%$ to $50 \%$ of the herbage under fairly hard sheep grazing management. In another pasture now in its tenth year, cocksfoot has provided about $21 \%$ of herbage over the last two years under a more lenient stocking system. A panui cocksfoot will persist under hard grazing and it remains good practice to include it in the normal permanent pasture mixture, especially on the drier soils. 
Kahu timothy has not been measured in a trial, but, in the pastures described above, this species has contributed from $2 \%$ to $7 \%$ in the harder-grazed pastures and the same as cocksfoot, $21 / 2 \%$, in the leniently-grazed pastures. The value of timothy appears to be in doubt and when used should be on the 'moister soils only.

Paspalum exhibits the same characteristics in farm pastures as in the Kaikohe trials. The better growth in dry weather of both the paspalum and its associated clover is evident. It is also evident that increasing stocking brings a decrease in paspalum. It is hoped that a trial just sown will measure the value of having even a small amount of paspalum in a mixed pasture. If paspalum is sown in a pasture mixture, and conditions for the establishment and maintenance of a vigorous pasture exist, there seems little chance of the paspalum ever contributing much. However, there arc areas of sand and dry coastal country where summer conditions are critical for ryegrass and even cocksfoot. In these situations, it seems advisable to establish paspalum and add other grasses later if possible.

Kikuyu pastures have been the highest producing pastures in Kaikohe trials. On the poorer alluvial soil, its own production was highest, but, on the volcanic soil, A riki ryegrass, Kikuyu and tall fescue produced about the same yields of sown grass, though with different seasonal productions. The evidence from these trials and from observation throughout Northland makes it obvious that detailed work should be done on the species. Because of this, a grazing trial has been established, to check on the value of this grass as a component of a mixed pasture. In addition, a programme of selection of an improved type has begun. At this stage, it is difficult to advise widespread use of Kikuyu. Where Kikuyu is al ready present, under most conditions, a high producing pasture can be developed if the outlook is towards using it as part of a species mixture, rather than as the sole grass. In some areas it appears difficult to establish paspalum, and in these cases Kikuyu would be worth trying.

Tall fescue also can be regarded as in the testing stage. Under the conditions of the trial, its seasonal and annual production was similar to that of A riki ryegrass. Relative unpalatability was apparent from early spring when flowering began, through to autumn. During the remainder of the year, palatability appeared good. When subjected to harder grazing than in the trial, it was observed that the species weakened more than cocksfoot, and volunteer grasses 
appeared in greater amount. It is suggested that this variety of tall fescue may not stand up well to competition from other sown or invading grasses.

White clover is by far the most important pasture legume available and is seldom omitted from a pasture mixture. As a legume, its main failings are in bloat promotion, poor grcwth under dry conditions, and low winter growth. There seems room for an improved variety of white clover.

Red clover seems to be a personal choice, in that many will not sow it because of the fear of bloat, or because of the retarding of white clover development. In the latter case, too heavy seedings and understocking are the main reasons. Under Northland conditions, 'Grasslands Hamua' broad red clover grows much better than white clover during the first winter and spring and its use could be regarded as analogous to that of Manawa ryegrass. The place of the late flowering red clover, 'Grasslands Turoa', is not so clear and further work needs to be done on it.

Subterranean clover (Trifolium subterraneum L.) is an annual legume of some importance under dry conditions and considerable use rightly is made of it.

Lotus major (Lotus pedunculatus) is present on very many soils and provides a great deal of feed under some lower production conditions. Its place under high production systems is not defined - certainly it will not compete with white clover where this will grow well. Some work is in progress at Kaikohe which may help in deciding how valuable the species is.

To sum up, it is thought that the basis of most highproducing pasture will continue to be ryegrass - Ruanui perennial and Ariki, and in some cases Manawa - cocksfoot and white clover. It may be possible to use paspalum in other than special situations. Kikuyu appears in the probable list, tall fescue in the possibles. The possibility of other species being found is not overlooked, and trials are in progress with some of these.

\section{REFERENCES}

Edmond, D. B. 1963: N.Z.J. agric. Res., 6: 265-76.

Goold, G. J. 1966: N.Z.J. Agric., 113 (4): 59-61.

Mitchell, K. J. 1963: Proc. N.Z. Inst. agric. Sci., 9: 80-96.

\section{DISCUSSION}

Could some details be given of growth techniques used in the trials?

Species were mown when at $4 \mathrm{in}$. in height, down to $1 \frac{1}{2} \mathrm{in}$. In the grazing trials, species grew to 4 in. between grazings and were grazed to $1 \frac{1}{2} \mathrm{in}$. 
In the last year of the trial, a three-weekly rate of growth technique was used.

What are the priorities when looking for other species? Is summer, winter, or all-round production looked for?

At present, we are looking for summer producers. Present ryegrasses responded to irrigation even with 11 in. of rain in January. Irrigation is not thought practical. Species which can make better use of soil water in summer are required. Most of the material at present comes from the high altitude tropics.

Could Mr Lambert suggest a pasture seed mixture for raw country, and one for improved country in this area?

It is unwise to be dogmatic about seed mixtures. At Kaikohe, the mixture used has been $10 \mathrm{lb}$ ryegrass $(5 \mathrm{lb}$ each of perennial and short rotation ryegrass), $5 \mathrm{lb}$ cocksfoot and $2 \mathrm{lb}$ white clover. Three pounds of red clover is often sown as well. There seems to be no reason for sowing more in practically any conditions. The use of Ariki ryegrass depends on soil fertility and pasture management, and I would not hesitate to substitute Ariki for perennial ryegrass now. The use of extra grass seed to compensate for poor cultivation is inadvisable; if extra seed is to compete with regenerating vegetation, it will compete with clover too. There may be a case for extra clover seed.

What are the details of application of extra water during the experiments7

Water was applied by sprinkler. All species received the same amount of water, which was based on the quantity required to maintain the soil in the perennial ryegrass plots at field capacity.

\section{Is there any scope for lucerne in Northland?}

The main problems are the unsuitable physical nature of many of the soils, low $\mathrm{pH}$ values, and high winter water levels. There is also the problem of weed growth. Lucerne has been tried but does not persist.

\section{Is there any information on the new white clover which incorporates the} Spanish variety?

We have a trial of this white clover at Kaikohe and it looks promising. Other trials throughout the country also show good results so far. 